\title{
Ongoing trials on COVID-19 treatments: please, don't forget Venous Thromboembolism!
}

\author{
Marco Zuin ${ }^{1,2} \cdot$ Giovanni Zuliani $^{1} \cdot$ Gianluca Rigatelli $^{2} \cdot$ Loris Roncon $^{2}$ (D)
}

Accepted: 2 December 2020 / Published online: 2 January 2021

(c) The Author(s), under exclusive licence to Springer Science+Business Media, LLC part of Springer Nature 2021

To the Editor,

As the COVID-19 pandemic continues evolving worldwide, several trials on COVID-19 disease are ongoing attempting to identify specific and efficient treatments. In this regard, over the latest weeks, some important and preliminary data have been published [1-3]. Doubtless, these studies have allowed to identify some drugs able to reduce the viral loads, improve the recovery time and probably prevent the progression to more severe pulmonary involvement. Unfortunately, venous thromboembolism (VTE), is frequently observed in COVID-19 patients, as well as acute pulmonary embolism (PE) $[4,5]$. Notably, recent published data obtained from randomized trials on Remdesivir [1,2] and Dexamethaosone [3], have not reported information on the thromboembolic complication rate in enrolled patients. Based on published data, we cannot deny that VTE, both asymptomatic or symptomatic, plays a crucial role in the clinical manifestations and evolution of COVID-19 infection as well as in the shortterm outcomes of these patients. In this regard, it would be helpful to have, despite difficult to perform, the more accurate global picture of tested treatments, since we cannot forget that their results have an immediate application in daily clinical practice, due to the ongoing pandemic. Doubtless, is it true that perform this type of studies, which are conducted during an "hostile" period, due to the considerable pressure on health care systems and physicians, is very difficult, but we cannot give up on the most comprehensive knowledge on this disease. The aim of considering VTE is beyond a potential thromboprophylactic effect of considered drugs.

Loris Roncon

lorisroncon@gmail.com

1 Department of Morphology, Surgery, and Medical Sciences, University of Ferrara, Ferrara, Italy

2 Department of Cardiology, Santa Maria Della Misericordia Hospital, Rovigo General Hospital Viale Tre Martiri, 45100 Rovigo, Italy
Nowadays anticoagulation can be achieved in several ways. Conversely, it would be important to obtain data on potential thromboembolic adverse effects of the tested drugs as well as potential adverse interaction with available anticoagulants use in daily clinical practice in COVID-19 patients. Moreover, whether antiviral agents, immunomodulating, anti-inflammatory or direct endothelial-vascular therapies might reduce or increase the likelihood of thrombotic events, must be clearly assessed before recommending their use in daily clinical practice. Too many times VTE has been forgotten in different clinical scenarios. Now, we cannot allow this.

Funding None.

\section{Compliance with ethical standards}

Conflicts of interest None of the authors have conflicts of interest to declare.

Ethical approval This article does not contain any studies with human participants or animals performed by any of the authors.

\section{References.}

1. Beigel JH, Tomashek KM, Dodd LE, Mehta AK, Zingman BS, Kalil AC, Hohmann E, Chu HY, Luetkemeyer A, Kline S, Lopez de Castilla D, Finberg RW, Dierberg K, Tapson V, Hsieh L, Patterson TF, Paredes R, Sweeney DA, Short WR, Touloumi G, Lye DC, Ohmagari N, Ohm MD, Ruiz-Palacios GM, Benfield T, Fätkenheuer G, Kortepeter MG, Atmar RL, Creech CB, Lundgren J, Babiker AG, Pett S, Neaton JD, Burgess TH, Bonnett T, Green M, Makowski M, Osinusi A, Nayak S, Lane HC, ACTT-1 Study Group Members (2020) Remdesivir for the treatment of Covid-19: final report. N Engl J Med. https://doi.org/10.1056/NEJMoa2007 764

2. Goldman JD, Lye DCB, Hui DS, Marks KM, Bruno R, Montejano R, Spinner CD, Galli M, Ahn MY, Nahass RG, Chen YS, SenGupta D, Hyland RH, Osinusi AO, Cao H, Blair C, Wei X, Gaggar A, Brainard DM, Towner WJ, Muñoz J, Mullane KM, Marty FM, 
Tashima KT, Diaz G, Subramanian A, GS-US-540-5773 Investigators (2020) Remdesivir for 5 or 10 days in patients with severe Covid-19. N Engl J Med. https://doi.org/10.1056/NEJMoa2015 301

3. RECOVERY Collaborative Group, Horby P, Lim WS, Emberson JR, Mafham M, Bell JL, Linsell L, Staplin N, Brightling C, Ustianowski A, Elmahi E, Prudon B, Green C, Felton T, Chadwick D, Rege K, Fegan C, Chappell LC, Faust SN, Jaki T, Jeffery K, Montgomery A, Rowan K, Juszczak E, Baillie JK, Haynes R, Landray MJ (2020) Dexamethasone in hospitalized patients with Covid-19: preliminary report. N Engl J Med. https://doi. org/10.1056/NEJMoa2021436

4. Nopp S, Moik F, Jilma B, Pabinger I, Ay C (2020) Risk of venous thromboembolism in patients with COVID-19: a systematic review and meta-analysis. Res Pract Thromb Haemost 4:1178-1191

5. Roncon L, Zuin M, Barco S, Valerio L, Zuliani G, Zonzin P, Konstantinides SV (2020) Incidence of acute pulmonary embolism in COVID-19 patients: systematic review and meta-analysis. Eur J Intern Med. https://doi.org/10.1016/j.ejim.2020.09.006

Publisher's Note Springer Nature remains neutral with regard to jurisdictional claims in published maps and institutional affiliations. 